Case Report

\title{
Meningocele in a Congolese Female with Beckwith-Wiedemann Phenotype
}

\author{
Sébastien Mbuyi-Musanzayi, ${ }^{1,2}$ Toni Lubala Kasole, ${ }^{2,3}$ Aimé Lumaka, ${ }^{4,5}$ \\ Tony Kayembe Kitenge, ${ }^{6}$ Leon Kabamba Ngombe, ${ }^{6}$ Prosper Kalenga Muenze, ${ }^{2,7}$ \\ Prosper Lukusa Tshilobo, ${ }^{4,5}$ François Tshilombo Katombe, ${ }^{1}$ \\ Célestin Banza Lubaba Nkulu, ${ }^{6}$ and Koenraad Devriendt ${ }^{5}$ \\ ${ }^{1}$ Department of Surgery, University Hospital, University of Lubumbashi, P.O. Box 1825, \\ Lubumbashi, Democratic Republic of the Congo \\ ${ }^{2}$ Center for Human Genetics, Faculty of Medicine, University of Lubumbashi, P.O. Box 1825, \\ Lubumbashi, Democratic Republic of the Congo \\ ${ }^{3}$ Department of Pediatrics, University Hospital, University of Lubumbashi, P.O. Box 1825, \\ Lubumbashi, Democratic Republic of the Congo \\ ${ }^{4}$ Department of Pediatrics, University Hospital, University of Kinshasa, P.O. Box 123, Kin XI, \\ Kinshasa, Democratic Republic of the Congo \\ ${ }^{5}$ Center for Human Genetics, University Hospital, KU Leuven, Campus Gasthuisberg, Herestraat 49, P.O. Box 602, \\ 3000 Leuven, Belgium \\ ${ }^{6}$ Unit of Toxicology and Environment, School of Public Health, University Hospital, University of Lubumbashi, \\ P.O. Box 1825, Lubumbashi, Democratic Republic of the Congo \\ ${ }^{7}$ Department of Gynecology, University Hospital, University of Lubumbashi, P.O. Box 1825, \\ Lubumbashi, Democratic Republic of the Congo \\ Correspondence should be addressed to Koenraad Devriendt; koenraad.devriendt@uzleuven.be
}

Received 18 October 2014; Accepted 3 December 2014; Published 28 December 2014

Academic Editor: Patrick Morrison

Copyright ( 2014 Sébastien Mbuyi-Musanzayi et al. This is an open access article distributed under the Creative Commons Attribution License, which permits unrestricted use, distribution, and reproduction in any medium, provided the original work is properly cited.

Beckwith-Wiedemann syndrome (BWS) is a rare congenital syndrome characterized by an overgrowth, macroglossia, exomphalos, and predisposition to embryonal tumors. Central nervous abnormalities associated with BWS are rare. We describe a one-day-old Congolese female who presented meningocele associated with BWS phenotype.

\section{Introduction}

Beckwith-Wiedemann syndrome (BWS) is a rare congenital disorder with an incidence of one in 13.700 live births [1, 2]. Initially, its designation was EMG (exomphalos-macroglossia-gigantism syndrome) and was characterized by a triad of an overgrowth, macroglossia, and exomphalos or umbilical hernia [3]. Other features were observed being associated with the triad, such as umbilical hernia, organomegaly (liver, spleen, or kidneys), neonatal hypoglycemia, minor ear anomalies, nevus flammeus, cleft palate, or embryonal tumor development $[4,5]$. The clinical features of BWS are variable, and it is accepted that the diagnosis can be established if three major diagnostic findings are present [6]. Its etiology is heterogeneous, arising from dysregulation of one or both imprinting control regions (IC) and/or imprinted growth regulatory genes of the chromosome 1lp15.5 [7]. BWS occurs with the same frequency in male and female [8]. Central nervous system anomalies are rare in BWS, but as far as we know not a single case has been described presenting meningocele. Here we present a female newborn who presented meningocele associated with the BWS phenotype. 


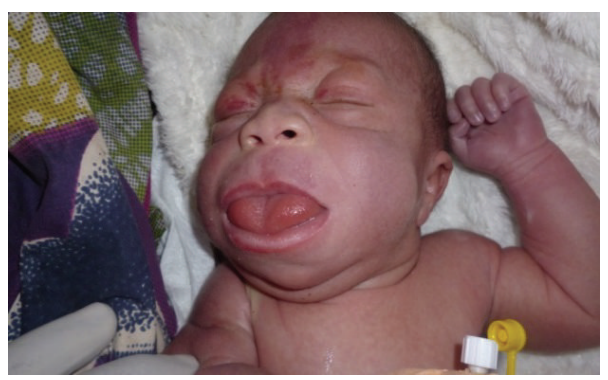

(a)

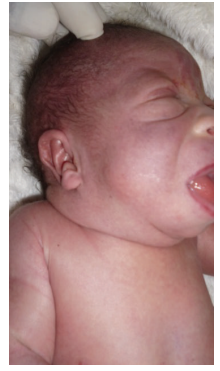

(b)

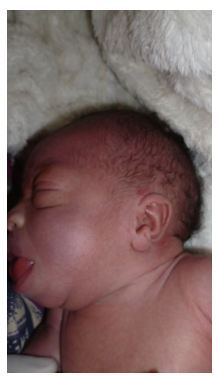

(c)

FIGURE 1: Facial signs: note (a) macroglossia and nevus flammeus on the face; (b) crumped helix on her right ear; (c) ear crease on the left lobe.

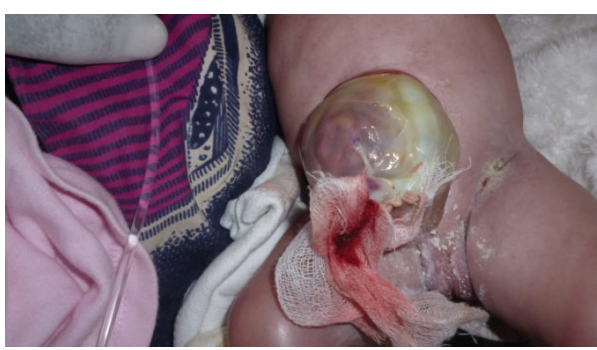

(a)

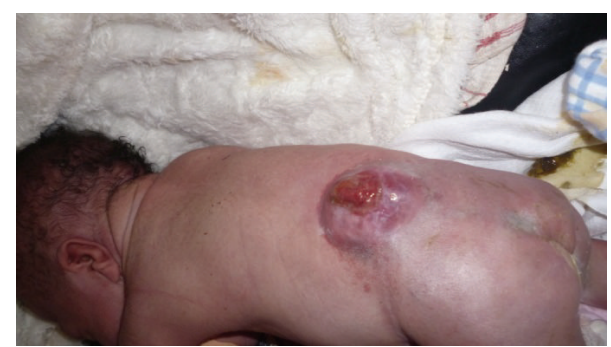

(b)

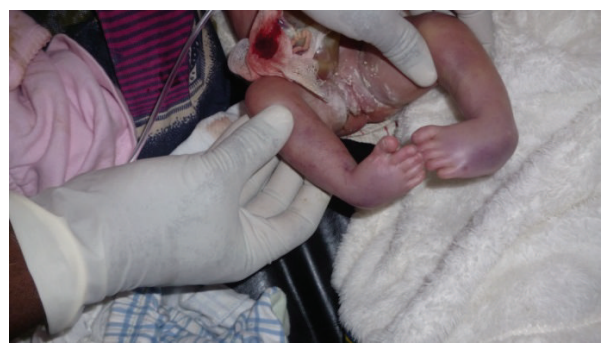

(c)

Figure 2: Other features: note (a) exomphalos, (b) meningocele, and (c) bilateral club feet.

\section{Case Report}

The index case is a one-day-old female, born at 39 weeks of gestation via normal spontaneous vaginal delivery with a birth weight of $4400 \mathrm{~g}$ (+4 SD, CDC growth charts). Her mother was 27 years, her father was 30 years old, and both were healthy and unrelated. Family history was marked by a primary infertility for 10 years. The mother had many gynecological consultations and medical treatment that she ignored during the last two years. During gestation she had a urinary infection treated with amoxicillin during the first trimester and treatment of threatened miscarriage. She took clay during the entire pregnancy. She received vaccination during the second trimester of gestation. Two prenatal ultrasound scans were performed, one during the first trimester and the second during the second trimester. Both did not show any anomaly. At birth on clinical examination, we observed macroglossia with protruding tongue, nevus flammeus on her face (Figure 1(a)). She presented crumped helix on her right ear and ear creases on the left lobe (Figures 1(b) and 1(c)). She had an omphalocele containing intestines (Figure 2(a)), a lumbosacral meningocele, and bilateral club feet (Figures 2(b) and 2(c)). She developed acute respiratory distress and died within six hours after birth.

\section{Discussion}

We present a newborn female, who presented an unusual association, meningocele associated with BWS phenotype. The diagnosis of BWS was based on the classical clinic triad of overgrowth, macroglossia, and exomphalos, associated with some additional minor features such as ear anomalies and frontal hemangioma. The diagnosis could not be confirmed by genetic studies, since the child died prematurely, before DNA could be obtained. The distinctive feature in the present case is lumbosacral meningocele. Central nervous abnormalities associated with BWS are rare, mostly involving 
TABLE 1: Central nervous features associated with BWS.

\begin{tabular}{|c|c|c|c|c|c|c|c|c|c|}
\hline Study & $\begin{array}{c}\text { Worth et al. } \\
{[9]} \\
1999\end{array}$ & $\begin{array}{l}\text { Yamada et } \\
\text { al. [10] } \\
1999\end{array}$ & $\begin{array}{l}\text { Tubbs and } \\
\text { Oakes [11] } \\
2005\end{array}$ & $\begin{array}{c}\text { Russo et al. } \\
{[12]} \\
2006\end{array}$ & $\begin{array}{c}\text { Broekman } \\
\text { et al. [13] } \\
2008\end{array}$ & $\begin{array}{c}\text { Kent et al. } \\
{[14]} \\
2008\end{array}$ & $\begin{array}{c}\text { Bui et al. } \\
{[15]} \\
2009\end{array}$ & $\begin{array}{l}\text { Gardiner et } \\
\text { al. [16] } \\
2012\end{array}$ & $\begin{array}{l}\text { This } \\
\text { report } \\
2014\end{array}$ \\
\hline \multicolumn{10}{|l|}{ Brain abnormalities } \\
\hline $\begin{array}{l}\text { Abnormal cerebellar } \\
\text { vermis }\end{array}$ & - & - & - & $+{ }^{*}$ & - & - & - & - & - \\
\hline $\begin{array}{l}\text { Arteriovenous } \\
\text { malformations }\end{array}$ & - & + & - & - & - & - & - & - & - \\
\hline Blake's pouch cyst & - & - & - & - & - & - & - & $2 / 7$ & - \\
\hline Chiari malformation & - & - & + & - & - & - & - & - & - \\
\hline $\begin{array}{l}\text { Dandy-Walker } \\
\text { malformation }\end{array}$ & - & - & - & - & - & - & - & $3 / 7$ & - \\
\hline $\begin{array}{l}\text { Dandy-Walker } \\
\text { variant }\end{array}$ & - & - & - & - & - & - & - & $4 / 7$ & - \\
\hline $\begin{array}{l}\text { Encephalocele } \\
\text { (nasal) }\end{array}$ & - & - & - & - & + & - & - & - & - \\
\hline Hydrocephalus & - & - & - & - & - & + & - & - & - \\
\hline $\begin{array}{l}\text { Posterior fossa } \\
\text { structures } \\
\text { abnormalities }\end{array}$ & - & - & - & - & - & - & + & - & - \\
\hline Schizencephaly & + & - & - & - & - & - & - & - & - \\
\hline Meningocele & - & - & - & - & - & - & - & - & + \\
\hline
\end{tabular}

${ }^{*}$ In this case, the associated terminal deletion of chromosome $4 \mathrm{p}$ may possibly explain the central nervous system malformation.

the brain (reviewed in Table 1). It is not excluded that this represents a chance association of two pathogenetically unrelated conditions, and the lack of genetic testing is a weakness of this report. Alternatively, given the previous reports of CNS anomalies in other cases with BWS, it is not excluded that the underlying genetic cause of BWS may also predispose to brain malformations (including neural tube defects), especially when imprinting defect involves the imprinting domain 2 at chromosome 11p15.5 [16].

\section{Conflict of Interests}

None of the authors has a conflict of interests to disclose in relation to this work.

\section{Authors' Contribution}

Sébastien Mbuyi-Musanzayi did clinical examination, treatment of the patient, and redaction of paper. Toni Lubala Kasole did clinical examination. Aimé Lumaka did paper correction. Tony Kayembe Kitenge did clinical examination. Leon Kabamba Ngombe did clinical examination. Prosper Lukusa Tshilobo and Prosper Kalenga Muenze did paper correction. François Tshilombo Katombe did clinical examination. Koenraad Devriendt did clinical examination, diagnosis, and paper corrections. All coauthors have read, contributed to, and approved the paper.

\section{Acknowledgments}

The authors thank the family of the patient for their kind cooperation and the Center for Human Genetics, KU Leuven, for support. Sébastien Mbuyi-Musanzayi was supported by a scholarship from interfaculty Council for Development Cooperation (IRO), KU Leuven, and GROS, Holsbeek (Belgium).

\section{References}

[1] W. Engstrom, S. Lindham, and P. Schofield, "WiedemannBeckwith syndrome," European Journal of Pediatrics, vol. 147, no. 5, pp. 450-457, 1988.

[2] M. J. Thorburn, E. S. Wright, C. G. Miller, and E. H. Smith-Read, "Exomphalos-macroglossia-gigantism syndrome in Jamaican infants," American Journal of Diseases of Children, vol. 119, no. 4, pp. 316-321, 1970.

[3] H. R. Wiedemann, "Familial malformation complex with umbilical hernia and macroglossia-a "new syndrome"?" Journal of Genetics in Human Molecular, vol. 13, pp. 223-232, 1964.

[4] J. R. Engel, A. Smallwood, A. Harper et al., "Epigenotype-phenotype correlations in Beckwith-Wiedemann syndrome," Journal of Medical Genetics, vol. 37, no. 12, pp. 921-926, 2000.

[5] J. Demars, Y. le Bouc, A. El-Osta, and C. Gicquel, "Epigenetic and genetic mechanisms of abnormal 11p15 genomic imprinting in Silver-Russell and Beckwith-Wiedemann syndromes," Current Medicinal Chemistry, vol. 18, no. 12, pp. 1740-1750, 2011.

[6] R. Weksberg, C. Shuman, and A. C. Smith, "Beckwith-Wiedemann syndrome," American Journal of Medical Genetics, vol. 137, no. 1, pp. 12-23, 2005.

[7] K. Delaval, A. Wagschal, and R. Feil, "Epigenetic deregulation of imprinting in congenital diseases of aberrant growth," BioEssays, vol. 28, no. 5, pp. 453-459, 2006.

[8] M. J. Pettenati, J. L. Haines, R. R. Higgins, R. S. Wappner, C. G. Palmer, and D. D. Weaver, "Wiedemann-Beckwith syndrome: 
presentation of clinical and cytogenetic data on 22 new cases and review of the literature," Human Genetics, vol. 74, no. 2, pp. 143-154, 1986.

[9] L. L. Worth, J. M. Slopis, and C. E. Herzog, "Congenital hepatoblastoma and schizencephaly in an infant with BeckwithWiedemann syndrome," Medical Pediatric Oncology, vol. 33, no. 6, pp. 591-593, 1999.

[10] K. Yamada, M. Miura, T. Ikeda, H. Miyayama, and Y. Ushio, "Ruptured arteriovenous malformation in a boy with BeckwithWiedemann syndrome," Pediatric Neurosurgery, vol. 31, no. 3, pp. 163-167, 1999.

[11] R. S. Tubbs and W. J. Oakes, "Beckwith-Wiedemann syndrome in a child with Chiari I malformation: case report," Journal of Neurosurgery, vol. 103, no. 2, pp. 172-174, 2005.

[12] S. Russo, P. Finelli, M. P. Recalcati et al., "Molecular and genomic characterisation of cryptic chromosomal alterations leading to paternal duplication of the 11p15.5 Beckwith-Wiedemann region," Journal of Medical Genetics, vol. 43, no. 8, p. e39, 2006.

[13] M. L. D. Broekman, E. W. Hoving, K. H. Kho, L. Speleman, K. S. Han, and P. W. Hanlo, "Nasal encephalocele in a child with Beckwith-Wiedemann syndrome: case report," Journal of Neurosurgery: Pediatrics, vol. 1, no. 6, pp. 485-487, 2008.

[14] L. Kent, S. Bowdin, G. A. Kirby, W. N. Cooper, and E. R. Maher, "Beckwith Weidemann syndrome: a behavioral phenotype-genotype study," American Journal of Medical Genetics Part B: Neuropsychiatric Genetics, vol. 147, no. 7, pp. 1295-1297, 2008.

[15] C. Bui, O. Picone, A. E. Mas et al., "Beckwith-Wiedemann syndrome in association with posterior hypoplasia of the cerebellar vermis," Prenatal Diagnosis, vol. 29, no. 9, pp. 906-907, 2009.

[16] K. Gardiner, D. Chitayat, S. Choufani et al., "Brain abnormalities in patients with Beckwith-Wiedemann syndrome," American Journal of Medical Genetics Part A, vol. 158, no. 6, pp. 13881394, 2012. 


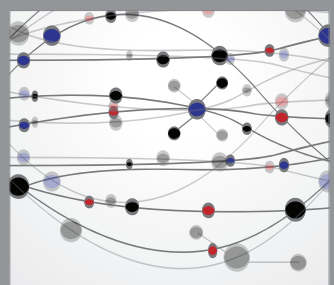

The Scientific World Journal
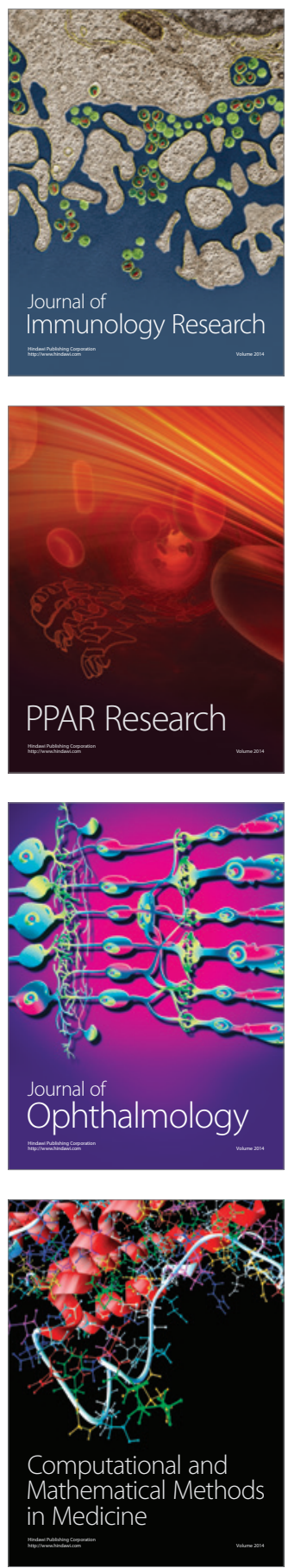

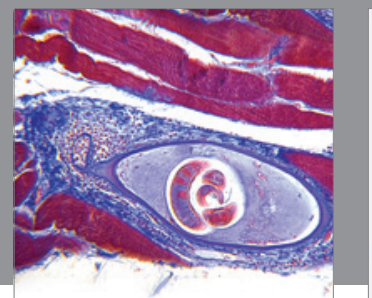

Gastroenterology

Research and Practice
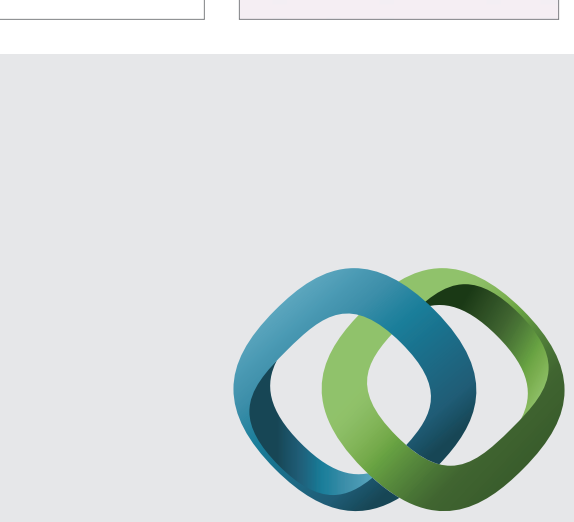

\section{Hindawi}

Submit your manuscripts at

http://www.hindawi.com
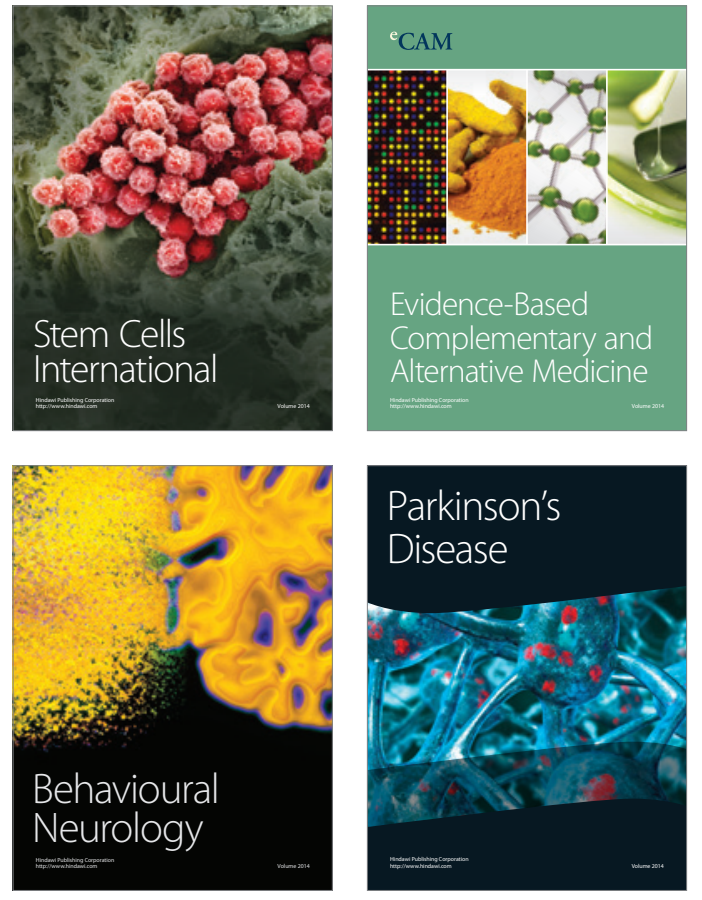
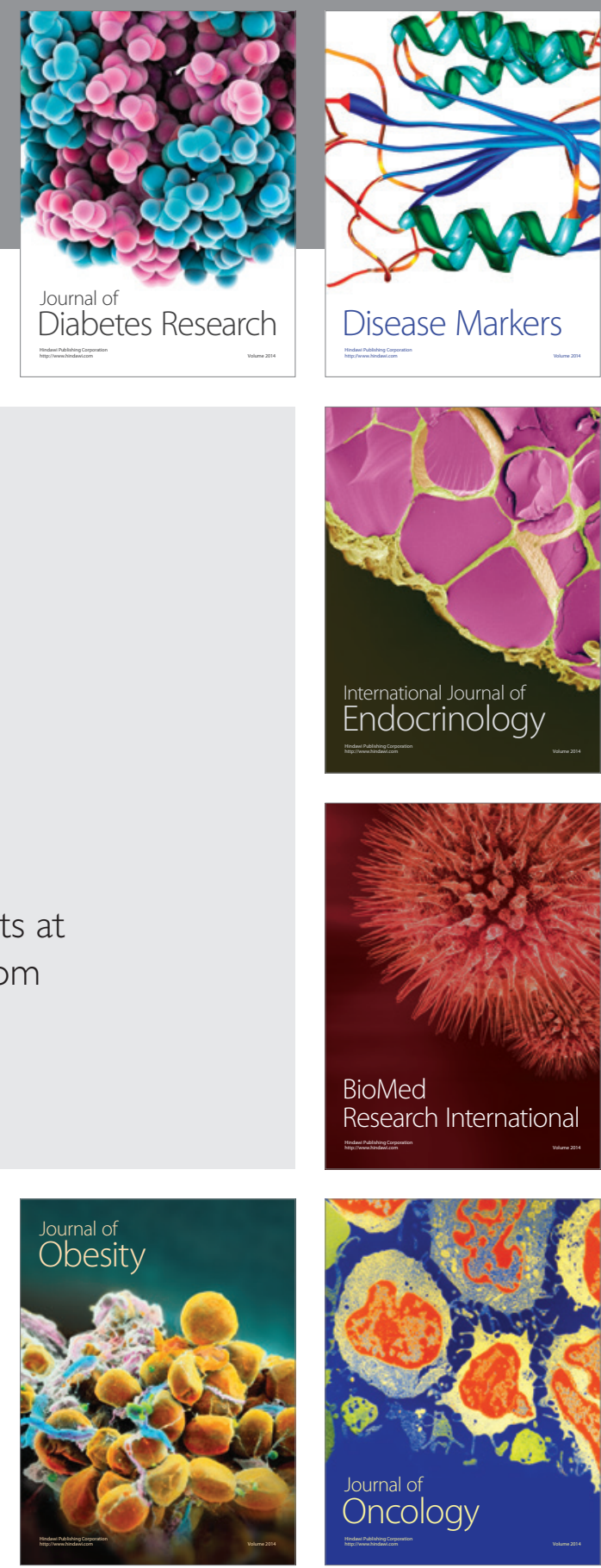

Disease Markers
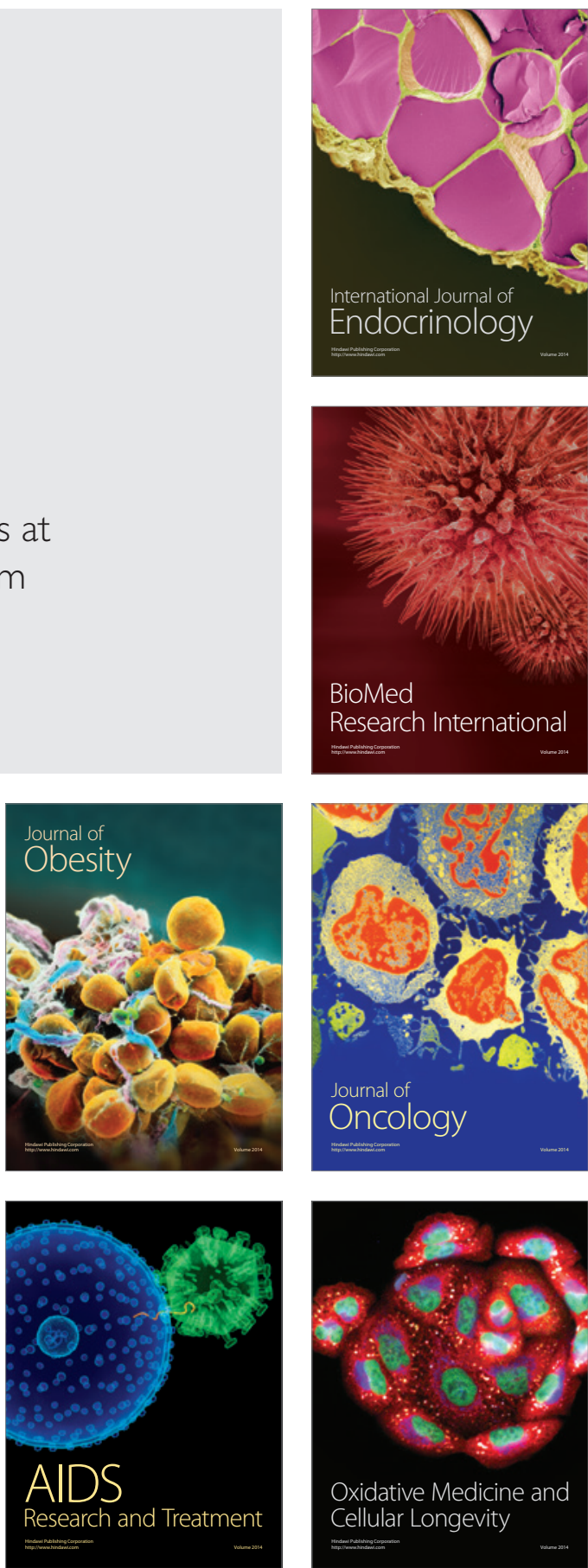